\title{
Handwashing revisited in dental practice during the COVID-19 outbreak
}

\author{
Soumia Ait-ou-amar ${ }^{1, A-D, F}$, Soumaya Berrazzouk ${ }^{2, A, B, F}$, Oumkeltoum Ennibi ${ }^{1, A, C-F}$ \\ ${ }^{1}$ Department of Periodontology, Faculty of Dental Medicine, Mohammed V University in Rabat, Morocco \\ ${ }^{2}$ Department of Conservative Dentistry and Oral and Facial Prosthodontics, Faculty of Dentistry, Complutense University of Madrid, Spain \\ A - research concept and design; $\mathrm{B}$ - collection and/or assembly of data; $\mathrm{C}$ - data analysis and interpretation; \\ $D$ - writing the article; $E$ - critical revision of the article; $F$ - final approval of the article
}

Address for correspondence

Soumia Ait-ou-amar

E-mail: soumaya_091@hotmail.com

Funding sources

None declared

Conflict of interest

None declared

Received on 0ctober 24, 2020

Reviewed on January 11, 202

Accepted on January 28, 2021

Published online on June 8, 202

Cite as

Ait-ou-amar S, Berrazzouk S, Ennibi 0. Handwashing revisited in dental practice during the COVID-19 outbreak. Dent Med Probl. 2021;58(2):243-252. doi:10.17219/dmp/132901

DOI

10.17219/dmp/132901

Copyright

○) 2021 by Wroclaw Medical University

This is an article distributed under the terms of the

Creative Commons Attribution 3.0 Unported License (CC BY 3.0)

(https://creativecommons.org/licenses/by/3.0/).

\begin{abstract}
Healthcare-associated infections are well-studied in the literature, but remain a significant challenge for healthcare workers (HCWs) in dental practice. This type of infection is strongly correlated with the hand route of transmission of infectious agents. Thus, hand hygiene can be considered a crucial element in the prevention and control of infections.

The coronavirus disease 2019 (COVID-19) outbreak is an experience of a new human coronavirus infection that has been difficult for HCWs, such as dentists and dental assistants, to control. Handwashing (HW) is a keystone method for the prevention and control of spreading severe acute respiratory syndrome coronavirus 2 (SARS-CoV-2).

In healthcare settings, contrary to the general consideration of HW as a simple practice, HW is regarded as a specific procedure that should be clearly instructed to HCWs. Handwashing is based on using a correct method and the necessary equipment, and its role should be continually emphasized to reinforce compliance. Proper HW might contribute to avoiding possible cross-infection during healthcare activities, particularly in the pandemic situation.

The aim of this article was to report on different HW techniques in medical and dental practice, and appropriate HW equipment to perform this simple but important procedure to prevent cross-infection, particularly during the current COVID-19 outbreak.
\end{abstract}

Keywords: hand hygiene, handwashing, cross-infection, COVID-19 outbreak 


\section{Introduction}

Handwashing (HW) is an effective measure for the prevention of cross-infection in healthcare settings. While providing dental care, cross-infection may occur directly from person to person, or indirectly via soiled instruments, clothes or hands. Pittet et al. reported that the hands could be the principal route of transmission of microorganisms. ${ }^{1}$

Hand skin exhibits endogenous and exogenous microflora. The endogenous flora grows on the deeper layers of the skin and on hair follicles. It is residential, commensal and specific for each individual. It renews rapidly, and it is almost impossible to remove it completely; it may act as a biological barrier. By contrast, the exogenous flora is transient, colonizes the superficial skin layers and is mostly acquired via environmental routes. This flora mainly consists of saprophytes, commensal bacteria and fungi of the oropharyngeal sphere, and digestive microorganisms that are transferred from patients. The exogenous flora is harmful and pathogenic, but can be easily removed by means of clinical HW procedures. ${ }^{2,3}$ In absence of correct hand hygiene, hand skin microflora, especially the exogenous flora, is frequently a source of the healthcare-related infections acquired while performing care activities. ${ }^{2-4}$ Hence, it is crucial to emphasize the key role of this simple but important activity in preventing cross-infection, particularly during the ongoing coronavirus disease 2019 (COVID-19) pandemic. This emergent outbreak is the $6^{\text {th }}$ public health emergency of international preoccupation, and the etiological agent - severe acute respiratory syndrome coronavirus 2 (SARS-CoV-2) - is the $3^{\text {rd }}$ most pathogenic human coronavirus that occurred in the last 2 decades. ${ }^{5,6}$ This new human betacoronavirus $(\beta \mathrm{CoV})$ is an RNA virus belonging to the Coronaviridae virus family. ${ }^{7}$ It has infectious potential through the respiratory droplets spread through coughing or sneezing by an infected individual, direct physical contact (e.g., shaking contaminated hands), or non-physical contact. ${ }^{3,7-9}$ Distant contamination can be explained by the dynamic turbulent gas model, which has shown that pathogenloaded droplets can circulate over a long distance. ${ }^{10,11}$ This may happen even if a patient is not showing signs of the disease (coughing or sneezing). ${ }^{6}$ According to previous studies, the moving turbulent gas can be transported over a distance of 23-27 feet, which corresponds to $7-8 \mathrm{~m}^{12-14}$

The viability of SARS-CoV-2 depends on its capacity to be stable on surfaces. Chin et al. reported that in vitro, the viral stability was up to $3 \mathrm{~h}$ on paper, 2 days on wood and fabrics, 4 days on glass and banknotes, and 7 days on stainless steel and plastic. ${ }^{15}$ Similarly, van Doremalen et al. reported that the viral stability of SARS-CoV-2 was higher on plastic and stainless steel than on copper and cardboard. ${ }^{16}$ Santarpia et al. reported significant environmental contamination in rooms where patients positive for SARS-CoV-2 were taken care of. ${ }^{17}$ Indeed, contamination was detected in all types of samples: air samples; personal items; room surfaces; and toilets. The presence of viral replication in the cell culture for some of the samples confirms the potential infectious nature of this virus. ${ }^{17}$ Smither et al. suggested in an experimental study that when the virus was transmitted within small-particle aerosols, it might remain viable for at least $90 \mathrm{~min} .{ }^{18}$ However, it is worth mentioning that SARS-CoV-2 is sensitive to standard disinfection methods, even though it has high stability in favorable environment. ${ }^{15}$

Thus, proper measures are needed to prevent this deadly virus. Handwashing is considered one of the essential control measures for preventing the spread of this infection by healthcare workers (HCWs) until effective antiviral therapy and vaccination are discovered..$^{5,8,19}$

The present review is a general overview of the importance of HW during the COVID-19 outbreak in dental practice. This review summarizes the mechanism of transmission of SARS-CoV-2, the HW procedure and the appropriate equipment needed to perform HW effectively in safe conditions. This work was designed as follows: the selection of databases was based on the principal electronic databases, i.e., MEDLINE/PubMed, Scopus (Elsevier), Science Direct Journals (Elsevier), and Google Scholar; the Medical Subject Headings (MeSH) terms used to search the articles were: "coronavirus", "coronavirus disease 2019", "COVID-19", "COVID-19 outbreak", “2019-nCoV", "SARS-CoV-2", "dental COVID-19", "dental COVID-19 outbreak", "dentistry COVID-19", "handwashing COVID-19", "hand hygiene", "cross-infection", and "healthcare workers", with the use of "AND" and "OR" between the MeSH terms. The retained articles were studies, reviews, and reports from international organizations focusing on HW during the COVID-19 outbreak in dental practice. Some earlier publications were included to understand the HW procedures and to overcome the lack of recent scientific studies regarding the issues.

\section{Compliance with handwashing in medical practice}

As cross-infection may occur in medical practice through HCWs' contaminated hands, HW is highly recommended. However, compliance with correct HW practice may vary among HCWs. Before the 1990s, it did not exceed $40 \%$ because of several factors..$^{20,21}$ Joshi et al. reported that differences in HW practice 
among various medical staff members were due to such factors as workload, accessibility to soap dispensers, hand irritation, hand dryness due to chemical irritants, and the level of awareness regarding hand hygiene. ${ }^{22}$ This study concluded that even though HCWs understood the importance of HW, they washed their hands selectively, depending on the situation. The majority of HCWs washed their hands after patient care rather than before. ${ }^{22}$ This raises the need to emphasize the importance of HW in medical practice, particularly in dental practice, where HW compliance is relatively low and the risk of infection is high. ${ }^{9}$ Thus, continuing education and training programs in medical settings could increase HCWs' HW compliance and the effectiveness of the procedures intended to prevent infectious diseases. ${ }^{23-26}$

During the outbreak of severe acute respiratory syndrome (SARS) in 2003 and Middle East respiratory syndrome (MERS) in 2012, numerous studies recognized the impact of these occurrences on raising HW awareness and compliance in community settings in the affected regions. However, applicable procedures generally failed to be properly implemented. ${ }^{23-25}$ Fung and Cairncross reported that a high fatality rate for SARS was a helpful factor to remind the individuals living in Hong Kong about the importance of HW, and that HW compliance increased and remained high for nearly 2 years after the outbreak. ${ }^{25}$ Therefore, the preventative measures applied during those previous health emergencies may be used as a guide for HCWs during the current COVID-19 outbreak, but also after this situation to prevent possible cross-infection and to constantly review HCWs' attitudes regarding protection against infections.

On March 11, 2020, the World Health Organization (WHO) announced that the COVID-19 outbreak was a pandemic phenomenon, and outlined numerous recommendations and guidelines to face the situation. ${ }^{27}$ The WHO's multimodal hand hygiene improvement strategy (MHHIS) in saving lives from COVID-19 global pandemic provides the evidence and the recommendations retained from the 2009 guidelines on hand hygiene in healthcare to support healthcare facilities. The following 5 key steps formed this approach ${ }^{28-30}$ :

- a change in the system that consists in providing permanent access to hand hygiene products (alcohol-based hand rubs (ABHR), water supply, soap, and towels);

- regular training and education for HCWs;

- the evaluation of HW and feedback (monitoring practices and knowledge);

- reminders in the workplace; and

- the promotion of an institutional safety climate with the active participation of all HCWs.

Several studies reported that the implementation of MHHIS brought overall good results all over the world with regard to staff education. ${ }^{16,17,31}$

\section{How and when to practice handwashing in dental practice?}

'Hand hygiene' is a general term referring to any action of hand cleansing involving $\mathrm{HW}$, antiseptic HW, antiseptic hand rubbing, or surgical hand antisepsis. ${ }^{30,32,33}$ Handwashing is a "procedure of washing hands with plain or antimicrobial soap and water"; it can be performed by means of different methods, depending on the risk of infection from healthcare activities. ${ }^{30,34}$ Three methods of HW can be practiced: routine HW; hygienic or antiseptic washing; and surgical washing (Table 1).

While HW can be considered a simple practice performed by everybody on an everyday basis, as a professional exercise, it needs to meet some specific requirements with respect to procedure and time (Fig. 1) 35,38 :

- the time required to achieve proper $\mathrm{HW}$ is $40-60 \mathrm{~s}$;

- all jewelry or other accessories should be removed before HW;

- the hands should be held upward after rinsing;

- the hands should be dried carefully with a single-use towel; the last towel should be used to turn the faucet off, if no automatic source is available, before throwing it into a pedal bin;

- regarding surgical HW, the procedure is finished by brushing the fingernails and the subungual areas, where the concentrations of microorganisms are high, with a sterilized brush with or without antiseptic solution; the brush should be used only for the fingernails and not for the skin, as it could create micro-cuts or erosions, which might lead to the exposure of the underlying cutaneous layers to microorganisms and possibly enable infection. ${ }^{2}$

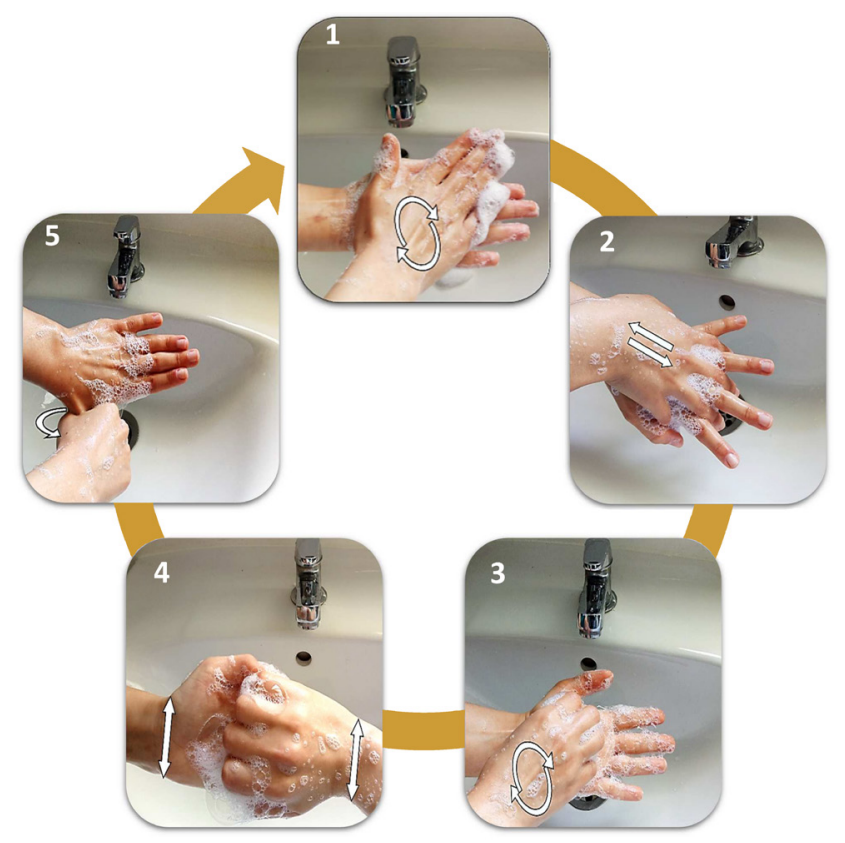

Fig. 1. Different steps of the professional handwashing (HW) procedure 
Table 1. Different professional handwashing (HW) methods, depending on clinical situations in dental practice 2,3,32,35-37

\begin{tabular}{|c|c|c|c|c|}
\hline Method & Purpose & Indication & Agent & Technique \\
\hline Routine HW & $\begin{array}{l}\text { - to eliminate the } \\
\text { transient flora }\end{array}$ & $\begin{array}{l}\text { low risk of infection } \\
\text { - when arriving to the } \\
\text { clinical department } \\
\text { and before leaving it } \\
\text { - between } 2 \text { patients } \\
\text { - between } 2 \text { activities } \\
\text { - before and after non- } \\
\text { invasive nursing care } \\
\text { activities } \\
\text { - before and after the } \\
\text { activities of everyday life }\end{array}$ & $\begin{array}{l}\text { - soft liquid soap } \\
\text { and a dispenser } \\
\text { - single-use paper } \\
\text { towels } \\
\text { - a faucet with } \\
\text { non-manual control } \\
\text { - a pedal bin }\end{array}$ & $\begin{array}{l}\text { minimal duration: } 30 \mathrm{~s} \\
\text { technique: } \\
\text { - denude hands and elbows } \\
\text { - wet hands and wrists } \\
\text { - apply a soap dose } \\
\text { - wash each hand while massaging, focusing on } \\
\text { the interdigital spaces, the perimeter of nails, } \\
\text { the pulp of fingers, and wrists } \\
\text { - rinse thoroughly } \\
\text { - dry hands by thoroughly wiping with single-use } \\
\text { paper towels } \\
\text { - turn off the faucet (if not automatic) with the last } \\
\text { paper towel used } \\
\text { - throw the paper towel into the bin without } \\
\text { touching it with your hands }\end{array}$ \\
\hline Surgical HW & $\begin{array}{l}\text { - to eliminate the } \\
\text { transient flora } \\
\text { - to reduce the } \\
\text { commensal flora } \\
\text { significantly } \\
(2-3 \log 10)\end{array}$ & $\begin{array}{l}\text { high risk of infection } \\
\text { - healthcare with a high risk } \\
\text { of infection: } \\
\text { - surgical activities } \\
\text { (endodontic surgery, } \\
\text { implant surgery, } \\
\text { alveolectomy, etc.) } \\
\text { - in operating rooms }\end{array}$ & $\begin{array}{l}\text { - antiseptic foaming } \\
\text { solution } \\
\text { - a sterile single-use } \\
\text { brush or a sterilized } \\
\text { soft brush in a single } \\
\text { bag } \\
\text { - sterile paper towels } \\
\text { - a faucet with } \\
\text { non-manual control } \\
\text { - a pedal bin }\end{array}$ & $\begin{array}{l}\text { duration: a total of about } 6 \text { min } \\
\text { it involves } 3 \text { stages: } \\
\text { - } 1^{\text {st }} \text { stage - prewash } \\
\text { - wet hands, wrists and forearms } \\
\text { - apply a dose of antiseptic soap and massage } \\
\text { thoroughly from fingertips to elbows for } 1 \text { min } \\
\text { - keep hands above elbows } \\
\text { - } \quad \text { rinse hands, wrists and forearms thoroughly } \\
\text { - } 2^{\text {nd }} \text { stage } \\
\text { - repeat a dose of soap and lather by massaging, } \\
\text { - } \text { taking the same technique } \\
\text { - } \text { rinse hand hands, wrists and forearms thoroughly } \\
\text { - } 3^{\text {rd }} \text { stage } \\
\text { - repeat a dose of soap, massage for } 1 \text { min (hands, } \\
\text { - wrists and forearms) and rinse } \\
\text { - pat dry with a sterile paper towel }\end{array}$ \\
\hline
\end{tabular}

Independently of healthcare activities and procedures, HW is an imperative procedure for any person who comes into contact with patients, principally HCWs, such as dentists and dental assistants, who are at particularly high risk of the SARS-CoV-2 infection during the present COVID-19 pandemic. $^{39,40}$

Handwashing is indicated once the hands get soiled or contaminated. ${ }^{41-43}$ Peng et al. defined specific indications with regard to HW for oral health professionals during the COVID-19 pandemic as follows: before and after routine dental examinations or procedures; after touching non-disinfected surroundings and equipment; and after touching the oral mucosa, damaged skin or wounds, blood, body fluids, secretions, and excreta. ${ }^{9}$ Ding et al. consider toilets as high-risk areas in hospitals with COVID-19 patients, and emphasize the strong need for hand and environmental hygiene as an intervention against the transmission of COVID-19. ${ }^{44}$ Indeed, contaminated aerosols may come from 3 possible sources: the exhaled release from patients when using the bathroom; toilet-generated aerosols when the toilets are flushed of feces and urine; and the import of airborne particles from the stalls. This proves that the use of toilets in healthcare areas might result in vector transmission, especially hand transmission. ${ }^{44,45}$

During the COVID-19 pandemic, HW is a crucial procedure, especially given the persistence of SARS-CoV-2. Indeed, this virus can be present on surfaces for a few hours up to several days, which exposes HCWs to a high risk of infection. There is no sufficient data concerning the viral load of coronaviruses on inanimate surfaces or the hands, and its transmissibility from contaminated surfaces to the hands in healthcare settings in an outbreak situation. ${ }^{46}$

Therefore, surface disinfection, especially of the frequently touched surfaces with the highest viral load, is important for preventing hand contamination. To ensure environmental cleaning and disinfection, the WHO recommends the consistent, correct and thorough cleaning of environmental surfaces with water 
and detergent as well as applying the commonly used hospital-level disinfectants, such as sodium hypochlorite, as effective and sufficient procedures. ${ }^{46,47}$ Several studies investigated which disinfectant agents should be used for surfaces and the hands to protect against SARS-CoV-2. Many formulations were tested to assess their rapidity, spectrum of microbicidal activity, accessibility, and safety (Table 2). Furthermore, to limit the risk of airborne contamination, different air purifiers are relevant during this pandemic (Table 3).

During the COVID-19 pandemic, hand-rub products are widely used in healthcare settings as one of the infection control tools. In routine medical practice, the ABHR formulations (ethanol or isopropanol agents) are commonly applied, as recommended by the WHO. ${ }^{30}$ However, their effectiveness appears to be limited and does not meet the European standards. ${ }^{72,73}$ Thus, modified formulations have been suggested. Suchomel et al. proposed the following modified formulations:

- the WHO I formulation (Formula 1):

ethanol $96 \% \mathrm{v} / \mathrm{v}+$ glycerol $98 \%$

$+\mathrm{H}_{2} \mathrm{O}_{2} 3 \%(6 \mathrm{~mL}$ in $60 \mathrm{~s})$;

- the modified WHO I formulation (Formula 2):

ethanol $80 \% \mathrm{w} / \mathrm{w}+$ glycerol $0.5 \% \mathrm{v} / \mathrm{v}$

$+\mathrm{H}_{2} \mathrm{O}_{2} 0.125 \% \mathrm{v} / \mathrm{v}(3 \mathrm{~mL}$ in $30 \mathrm{~s})$;

- the WHO II formulation (Formula 3):

isopropanol (with a purity of 99.8\%) + glycerol 98\%

$+\mathrm{H}_{2} \mathrm{O}_{2} 3 \%$ (6 mL in $\left.30 \mathrm{~s}\right)$;

- and the modified WHO II formulation (Formula 4):

isopropanol $75 \% \mathrm{w} / \mathrm{w}+$ glycerol $0.5 \% \mathrm{v} / \mathrm{v}$

$+\mathrm{H}_{2} \mathrm{O}_{2} 0.125 \% \mathrm{v} / \mathrm{v}(3 \mathrm{~mL}$ in $30 \mathrm{~s}){ }^{74}$
In light of the ongoing circumstances, several reports from international organizations ${ }^{40,75-78}$ recommend the use of medical gloves as part of the personal protective equipment (PPE) to strengthen protection against potentially infectious biologic secretions. ${ }^{39} \mathrm{Ye}$ et al. reported that gloves were the PPE most contaminated with SARS-CoV-2 at $15.4 \%{ }^{79}$ Hence, wearing gloves should not be an alternative to HW in healthcare practice, mainly because of rapid bacterial proliferation due to the humidity of the hands under the surface of gloves and the deterioration of gloves. ${ }^{4,80}$

Additionally, HCWs should observe further precautions concerning the route of transmission of microorganisms by avoiding touching their face, eyes, mouth, and nose. ${ }^{9}$ Macias et al. reported that during the influenza A (H1N1) pandemic, face touching behavior was commonly observed on average 3.3 times per hour in the community. ${ }^{81}$ It was also reported that face touching behavior among medical students with their own hands was observed on average 23 times per hour, with contact mostly to the skin (56\%), followed by mouth (36\%), nose (31\%), and eyes (31\%). ${ }^{82}$ These results cannot be generalized to all HCW categories because of several factors, such as the duration of the experiment and the degree of awareness. However, they illustrate the higher risk of infection HCWs face as compared to the rest of the community, which makes HW procedures an effective and inexpensive preventative method to break the colonization and transmission cycle from the autoinoculation route, and to minimize the spread of infection. ${ }^{82}$ Furthermore, to avoid potential nosocomial infection, it is recommended to have short fingernails, no nail polish and no jewelry; otherwise, contamination can frequently occur even with proper HW. ${ }^{83-87}$

To summarize the timings of HW, the WHO recommends "My Five Moments for Hand Hygiene" approach as guidelines for dental practice as follows: before touching a patient; before clean/aseptic procedure; after body fluid exposure risk; after touching a patient; and after touching patient surroundings. ${ }^{86}$

Table 2. Effectiveness of different types of disinfectant agents at various concentrations [\%] against severe acute respiratory syndrome coronavirus (SARS-CoV)

\begin{tabular}{|c|c|c|}
\hline Disinfectant agent & Concentration for surface use and exposition time & Concentration for hand use and exposition time \\
\hline Ethanol & $70-90 \% / 30 s^{48,49}$ & $80 \% \mathrm{v} / \mathrm{v}, 85 \% \mathrm{v} / \mathrm{v}$ and $95 \% \mathrm{v} / \mathrm{v}$ UND / $30 \mathrm{~s}{ }^{48,55}$ \\
\hline Isopropanol & $70 \%$ and $75 \% / 30 s^{50,51}$ & $75 \% \mathrm{w} / \mathrm{w} \mathrm{D}$ to $20 \% / 30 \mathrm{~s}^{50,56}$ \\
\hline Formaldehyde & $0.5-3 \% / 2 \min 49,51$ & $0.7-1 \% / 2 \min 51,57$ \\
\hline Glutardialdehyde & $0.5 \% / 2 \min ^{49,51}$ & $0.5 \% / 2 \min ^{51,57}$ \\
\hline Povidone-iodine & $0.23-1 \% / 15 s^{49,52}$ & $0.5-10 \% / 15 s^{52,57}$ \\
\hline Sodium hypochlorite & $0.5 \%(5,000 \mathrm{ppm}) / 1 \min ^{46,53}$ & $<5 \%(0.05-0.21 \%) /<1 \min ^{57}$ \\
\hline Hydrogen peroxide & $1-3 \% / 1 \min 49,54$ & $0.125 \% \mathrm{v} / \mathrm{v} D$ to $40-80 \% / 30 \mathrm{~s}^{50,56}$ \\
\hline Triclosan/triclocarban & - & $1-2 \% /<1 \min 55,58$ \\
\hline Chlorhexidine & \multicolumn{2}{|c|}{$\begin{array}{l}\text { lower effectiveness against SARS-CoV is due to lower capacity to inactivate the enveloped human coronavirus, } \\
\text { and also to some environmental factors (cold temperatures, external humidity and pH) })^{57,59}\end{array}$} \\
\hline
\end{tabular}


Table 3. Air disinfection procedures against severe acute respiratory syndrome coronavirus (SARS-CoV)

\begin{tabular}{|c|c|c|c|c|}
\hline & Procedure types & Disinfection properties & Advantages & Disadvantages \\
\hline UVG| ${ }^{60,61-63}$ & $\begin{array}{l}\text { - UVGI types: } \\
\text { - UV-A WL: } 315-380 \mathrm{~nm} \\
\text { - UV-B WL: 280-315 nm } \\
\text { - UV-C WL: 100-280 nm } \\
\text { - UVGI options: } \\
\text { - UV-C flow germicidal lamps } \\
\text { - contaminated air drawn } \\
\text { through a filter } \\
\text { - UV-C direct radiation tubes } \\
\text { - direct disinfection of the } \\
\text { whole room } \\
\text { - dual-function UV-C flow } \\
\text { germicidal lamps - combining } \\
\text { the } 2 \text { above options }\end{array}$ & $\begin{array}{l}\text { - } \text { bactericidal and virucidal } \\
\text { activity } \\
\text { - SARS-CoV-2 is highly } \\
\text { susceptible to UV-C damage } \\
\text { at a dose } 0.377-0.590 \mathrm{~J} / \mathrm{m}^{2}\end{array}$ & $\begin{array}{l}\text { - important role in reducing } \\
\text { the risk of transmission } \\
\text { of coronaviruses, such } \\
\text { as SARS-CoV-1, MERS } \\
\text { and SARS-CoV-2 } \\
\text { - disinfection effectiveness is } \\
\text { improved by the addition } \\
\text { of UV-C radiation for } \\
\text { 20-30 min after cleaning } \\
\text { between } 2 \text { patients }\end{array}$ & $\begin{array}{l}\text { - UV-C light disinfection may } \\
\text { not always be effective due to } \\
\text { a low penetration depth } \\
\text { - access to rooms with UV-C } \\
\text { direct radiation tubes should } \\
\text { be denied to everyone } \\
\text { - lower light effectiveness for } \\
\text { the objects situated far away } \\
\text { from the source of UV-C light }\end{array}$ \\
\hline Air fogging $60,64,65$ & $\begin{array}{l}\text { - hydrogen peroxide } \\
\text { processing forms: } \\
\text { - vaporized hydrogen } \\
\text { peroxide } \\
\text { - aerosolized hydrogen } \\
\text { peroxide } \\
\text { - the gaseous form is more } \\
\text { effective than the liquid form }\end{array}$ & $\begin{array}{l}\text { - bactericidal, virucidal, } \\
\text { fungicidal, and sporicidal } \\
\text { activity }\end{array}$ & $\begin{array}{l}\text { - hydrogen peroxide is the } \\
\text { recommended agent for daily } \\
\text { use in enclosed healthcare } \\
\text { areas }\end{array}$ & $\begin{array}{l}\text { - rooms should be evacuated } \\
\text { and pre-cleaned of visible dirt } \\
\text { - rooms cannot be immediately } \\
\text { occupied after disinfection } \\
\text { - physical irritation of the mucous } \\
\text { membranes, the eyes, skin, } \\
\text { and lungs is possible } \\
\text { - users need to be trained }\end{array}$ \\
\hline $\begin{array}{l}\text { Photocatalytic } \\
\text { disinfection } 60,66,67\end{array}$ & $\begin{array}{l}\text { - titanium dioxide filters } \\
\text { stimulated by UV radiation }\end{array}$ & $\begin{array}{l}\text { - effective against a wide } \\
\text { range of Gram-negative and } \\
\text { Gram-positive bacteria, fungi, } \\
\text { protozoa, and viruses } \\
\text { - effective against SARS-CoV-1, } \\
\text { with a high probability } \\
\text { of virucidal effect on } \\
\text { SARS-CoV-2 }\end{array}$ & $\begin{array}{l}\text { - high potential for inactivating } \\
\text { pathogens, increased by } \\
\text { the use of silver and titanium } \\
\text { dioxide filters }\end{array}$ & $\begin{array}{l}\text { - disinfection effectiveness } \\
\text { is influenced by the design } \\
\text { of the device and the indoor } \\
\text { air properties (relative } \\
\text { humidity, temperature } \\
\text { and the composition } \\
\text { of contaminated air) }\end{array}$ \\
\hline Plasma ${ }^{60,68,69}$ & $\begin{array}{l}\text { - non-thermal plasma adapted } \\
\text { for biological applications }\end{array}$ & $\begin{array}{l}\text { - biocidal effect on viruses, } \\
\text { bacteria, spores or fungi, } \\
\text { and prions, with little impact } \\
\text { on the structural integrity } \\
\text { of disinfected surfaces }\end{array}$ & $\begin{array}{l}\text { - can be used in several devices } \\
\text { to address air disinfection } \\
\text { - safe and non-toxic for } \\
\text { the environment } \\
\text { - easy to handle } \\
\text { - inexpensive }\end{array}$ & $\begin{array}{l}\text { - new technique that is not } \\
\text { largely used }\end{array}$ \\
\hline $\begin{array}{l}\text { Ozone } \\
\text { generators }{ }^{60,70,71}\end{array}$ & - ozone gas & $\begin{array}{l}\text { - } \text { bactericidal, virucidal } \\
\text { and fungicidal activity } \\
\text { - ozonation effectiveness } \\
\text { against coronaviruses } \\
\text { at } 100 \text { ppm/30 min }\end{array}$ & $\begin{array}{l}\text { - easy penetration into all areas } \\
\text { of the room and all objects }\end{array}$ & $\begin{array}{l}\text { - rooms must be evacuated } \\
\text { and enclosed } \\
\text { - not the first choice as } \\
\text { a disinfection method, since } \\
\text { ozone is toxic } \\
\text { - effective ventilation systems } \\
\text { are required as well as the } \\
\text { measures taken to check } \\
\text { that residual ozone has been } \\
\text { efficiently eradicated } \\
\text { - corrosion risk for some materials }\end{array}$ \\
\hline
\end{tabular}

UVGI - ultraviolet germicidal irradiation; UV - ultraviolet; WL - wavelength.

\section{Professional handwashing materials}

In medical areas, a well-planned HW equipment set-up (washbasins, liquid soap dispensers, and hand wiping and drying systems) can protect HCWs from potential nosocomial infection and ensure correct HW. Indeed, Coleman et al. reported that contaminated washbasins and sink drain outlets were associated directly or indirectly with the hospital outbreaks of infection. ${ }^{6}$ Ye et al. reported that hand sanitizer dispensers accounted for about $20.3 \%$ of contaminated objects. ${ }^{79}$ Therefore, HW materials (washbasins, liquid soap dispensers, etc.) can be considered a possible source of microbial biofilm proliferation, and thus require good maintenance, regular cleaning and exclusive use for HW by HCWs. ${ }^{6,79}$

With regard to HW agents, it is recommended to apply those indicated for professional medical use. ${ }^{87}$ These agents generally have the following features: are not perfumed; rarely induce allergic reactions; and are suitable for everyday use. Professional HW is based on the treatment of the hands with regular liquid soap or an antimicrobial product (soap, gel or solution), with the spectrum of activity targeted at microorganisms that are part of the cutaneous flora to prevent their transmission. ${ }^{76}$ Such products contain emollients, e.g., glycerine or aloe vera, that promote hand health and comfort. 
These components have a softening effect that prevents the occurrence of dermatitis, which may result from frequent HW, and also helps to ensure HW compliance. ${ }^{58}$ However, the specificity of the products indicated for antiseptic or surgical washing, as compared to simple wash products, consists in their net, rapid and persistent bactericidal and virucidal effect for several hours on the cutaneous flora of the hands. ${ }^{88}$ The products commonly used in medical practice are based on chlorhexidine from $2 \%$ up to $4 \%$, alcohols between $60 \%$ and $70 \%$, or iodine-based compounds. ${ }^{2,4,32}$ Regarding the soap form, bar soap should be avoided in hospitals to prevent creating a microbial niche that is consequently a source of contamination, unless it is intended for single use. ${ }^{37}$ According to several studies, bar soap can be a reservoir of various microorganisms and using it in hospital practice can transform $\mathrm{HW}$ into a vehicle for spreading infections, such as gastrointestinal infection, respiratory infection or cutaneous infection, including the SARS-CoV-2 respiratory infection. ${ }^{22,89,90}$ Thus, liquid soap is highly recommended instead of bar soap. Nevertheless, the risk related to the soap dispenser system must be controlled. The soap refill is screwed into the system and the liquid flows by gravity. To avoid contamination, the last drop should not be sucked into the cartridge, and the valves should be operated with the elbow to avoid direct contact with the soap dispenser.

In addition, the manual water faucets commonly installed in healthcare settings should be avoided because of the risk of infection and contamination. To avoid manual contact, the faucet should be controlled by a pedal or the elbow. Ideally, an automatic faucet (electro-sensitive) with a sufficiently large and deep washbasin to avoid splashing contamined water should be used for HW. Notably, the area reserved for HW should be independent of the instrument disinfection area. ${ }^{37}$ For simple washing and antiseptic washing, warm water is more recommended than water of extreme temperature (hot or cold) to avoid cutaneous irritation and dryness. ${ }^{58}$ Regarding surgical HW, using pure water is practiced; according to the microbiological quality control standards, 'clean water' is of level 1 , which is obtained by the chlorination $(0.1 \mathrm{mg} / \mathrm{L})$ chemical treatment of the water supply. ${ }^{91}$

After HW, meticulous hand drying is the final and necessary step to prevent the transmission of microorganisms, which is caused more often by wet hands than by dry hands due to the nature of the clinical practice, frequently exposing HCWs' hands to wetness. In contrast, hand drying may decrease the number of microorganisms translocated through touch. ${ }^{91,92}$ For wiping hands, single-use hand towels are recommended after simple and hygienic $\mathrm{HW}$, and sterile hand towels after surgical HW. In general, the following characteristics of hand towels are recommended for safe hand drying: they should be absorbent; flexible to fit the hand's anatomy; and resistant to tearing. The hand drying system has an influence on the protection against cross-infection.
Apart from being slow and noisy, electric hand dryers are to be avoided in healthcare settings because, according to some studies, the waterborne microorganisms dispersed by hand dryers can become aerosols. ${ }^{2}$ Kimmitt and Redway studied hand drying methods by comparing paper towels, a warm air dryer and a jet air dryer for their potential to disperse viruses and contaminate the immediate environment during use. ${ }^{93}$ They found that the use of a jet air dryer led to a significantly greater and further dispersal of microorganisms from artificially contaminated hands as compared to paper towels and a warm air dryer. ${ }^{93}$ Hence, it is necessary to make a careful choice of the hand drying system in healthcare settings, where the risk of cross-infection is high, especially during critical situations like the present outbreak, to safeguard patients and HCWs. ${ }^{92,93}$ It is worth noting that before wearing gloves, HCWs should dry their hands completely after hand disinfection, as residual humidity, such as that from $A B H R$, may increase the risk of glove perforation during daily dental care. ${ }^{94}$ Lastly, for collecting used hand towels, a pedal bin installation is required near the HW set-up to avoid touching the bin, and thus to limit the risk of contamination of HCWs' hands.

\section{Conclusions}

In medical practice, $\mathrm{HW}$ is a basic measure for preventing the transmission of germs and the spread of infection related to healthcare activities. The occurrence of more or less serious nosocomial infection is a real risk in dental practice, and prevention concerns are paramount. Hence, HW is a very important and simple - but indispensable - procedure to prevent the manual transmission of germs.

\section{ORCID iDs}

Soumia Ait-ou-amar (1) https://orcid.org/0000-0002-9602-1732 Soumaya Berrazzouk (D) https://orcid.org/0000-0002-1969-2292 Oumkeltoum Ennibi (D) https://orcid.org/0000-0002-1224-9124

\section{References}

1. Pittet D, Allegranzi B ,Storr J, et al. Infection control as a major World Health Organization priority for developing countries. J Hosp Infect. 2008;68(4):285-292. doi:10.1016/j.jhin.2007.12.013

2. Ontario Agency for Health Protection and Promotion (Public Health Ontario), Provincial Infectious Diseases Advisory Committee. Best Practices for Hand Hygiene in All Health Care Settings. $4^{\text {th }}$ ed. Toronto, Canada: Queen's Printer for Ontario; 2014. https://www.publichealthontario.ca/-/media/documents/b/2014/bp-hand-hygiene.pdf?la=en. Accessed October 19, 2020.

3. Samaranayake LP, Peiris M. Severe acute respiratory syndrome and dentistry: A retrospective view. J Am Dent Assoc. 2004;135(9):1292-1302. doi:10.14219/jada.archive.2004.0405

4. Naik S, Khanagar S, Kumar A, Vadavadagi S, Neelakantappa HM Ramachandra S. Knowledge, attitude, and practice of hand hygiene among dentists practicing in Bangalore city - a crosssectional survey. J Int Soc Prevent Community Dent. 2014;4(3):159-163. doi:10.4103/2231-0762.142013 
5. Lai CC, Shih TP, Ko WC, Tang HJ, Hsueh PR. Severe acute respiratory syndrome coronavirus 2 (SARS-CoV-2) and coronavirus disease-2019 (COVID-19): The epidemic and the challenges. Int J Antimicrob Agents. 2020;55(3):105924. doi:10.1016/j.jjantimicag.2020.105924

6. Coleman DC, Deasy EC, Moloney EM, Swan JS, O'Donnell MJ. Decontamination of hand washbasins and traps in hospitals. In: Walker J, ed. Decontamination in Hospitals and Healthcare. $2^{\text {nd }}$ ed. Woodhead Publishing Series in Biomaterials; 2020:135-161. doi:10.1016/B978-0-08-102565-9.00007-8

7. Rothan HA, Byrareddy SN. The epidemiology and pathogenesis of coronavirus disease (COVID-19) outbreak. J Autoimmun. 2020;109:102433. doi:10.1016/j.jaut.2020.102433

8. Ather A, Patel B, Ruparel NB, Diogenes A, Hargreaves KM. Coronavirus disease 19 (COVID-19): Implications for clinical dental care. J Endod. 2020;46(5):584-595. doi:10.1016/j.joen.2020.03.008

9. Peng X, Xu X, Li Y, Cheng L, Zhou X, Ren B. Transmission routes of $2019-n C o V$ and controls in dental practice. Int $J$ Oral Sci. 2020;12(1):9. doi:10.1038/s41368-020-0075-9

10. Bourouiba L. Turbulent gas clouds and respiratory pathogen emissions: Potential implications for reducing transmission of COVID19. JAMA. 2020;323(18):1837-1838. doi:10.1001/jama.2020.4756

11. Seminara G, Carli B, Forni G, Fuzzi S, Mazzino A, Rinaldo A. Biological fluid dynamics of airborne COVID-19 infection. Rend Lincei Sci Fis Nat. 2020:1-33. doi:10.1007/s12210-020-00938-2

12. Scharfman BE, Techet AH, Bush JWM, Bourouiba L. Visualization of sneeze ejecta: Steps of fluid fragmentation leading to respiratory droplets. Exp Fluids. 2016;57(2):24. doi:10.1007/s00348-015-2078-4

13. Bourouiba L, Dehandschoewercker E, Bush JWM. Violent respiratory events: On coughing and sneezing. J Fluid Mech. 2014;745:537-563. doi:10.1017/jfm.2014.88

14. Bourouiba L. Images in clinical medicine. A Sneeze. N Engl J Med. 2016;375(8):e15. doi:10.1056/nejmicm1501197

15. Chin AWH, Chu JTS, Perera MRA, et al. Stability of SARS-CoV-2 in different environmental conditions. Lancet Microbe. 2020;1(1):e10. doi:10.1016/S2666-5247(20)30003-3

16. van Doremalen N, Bushmaker T, Morris DH. Aerosol and surface stability of SARS-CoV-2 as compared with SARS-CoV-1. N Engl J Med. 2020;382(16):1564-1567. doi:10.1056/NEJMc2004973

17. Santarpia JL, Rivera DN, Herrera VL, et al. Aerosol and surface contamination of SARS-CoV-2 observed in quarantine and isolation care. Sci Rep. 2020;10(1):12732. doi:10.1038/s41598-020-69286-3

18. Smither SJ, Eastaugh LS, Findlay JS, Lever MS. Experimental aerosol survival of SARS-CoV-2 in artificial saliva and tissue culture media at medium and high humidity. Emerg Microbes Infect. 2020;9(1):1415-1417. doi:10.1080/22221751.2020.1777906

19. Lai THT, Tang EWH, Chau SKY, Fung KSC, Li KKW. Stepping up infection control measures in ophthalmology during the novel coronavirus outbreak: An experience from Hong Kong. Graefes Arch Clin Exp Ophthalmol. 2020;258(5):1049-1055. doi:10.1007/s00417-020-04641-8

20. Allegranzi B, Stewardson AJ, Pittet D. Compliance with hand hygiene best practices. In: Pittet D, Boyce JM, Allegranzi B, eds. Hand Hygiene: A Handbook for Medical Professionals. Hoboken, USA: Wiley Blackwell; 2017:76-84. doi:10.1002/9781118846810.ch11

21. Pittet D, Hugonnet $S$, Harbarth $S$, et al. Effectiveness of a hospitalwide program to improve compliance with hand hygiene. Infection Control Programme. Lancet. 2000;356(9238):1307-1312. doi:10.1016/S0140-6736(00)02814-2

22. Joshi SK, Joshi A, Park BJ, Aryal UR. Hand washing practice among health care workers in a teaching hospital. J Nepal Health Res Counc. 2013;11(23):1-5. doi:10.33314/jnhrc.v0i0.353

23. Yang J, Park EC, Lee SA, Lee SG. Associations between hand hygiene education and self-reported hand-washing behaviors among Korean adults during MERS-CoV outbreak. Health Educ Behav. 2019;46(1):157-164. doi:10.1177/1090198118783829

24. Alshammari M, Reynolds KA, Verhougstraete M, O'Rourke MK. Comparison of perceived and observed hand hygiene compliance in healthcare workers in MERS-CoV endemic regions. Healthcare (Basel). 2018;6(4):122. doi:10.3390/healthcare6040122

25. Fung $\mathrm{ICH}$, Cairncross S. How often do you wash your hands? A review of studies of hand-washing practices in the community during and after the SARS outbreak in 2003. Int J Environ Health Res. 2007;17(3):161-183. doi:10.1080/09603120701254276
26. Novák M, Breznický J, Kompaníková J, Malinovská N, Hudečková H. Impact of hand hygiene knowledge on the hand hygiene compliance. Med Glas (Zenica). 2020;17(1):194-199. doi:10.17392/1051-20

27. World Health Organization. WHO Director-General's opening remarks at the media briefing on COVID-19-11 March 2020. https:// www.who.int/dg/speeches/detail/who-director-general-s-opening-remarks-at-the-media-briefing-on-covid-19---11-march-2020. Accessed November 19, 2020.

28. World Health Organization. WHO saves lives: Clean your hands, May 5, 2019. "Clean care for all-it's in your hands." https://www. who.int/infection-prevention/campaigns/clean-hands/advocacyslides-2019_long.pdf?ua=1. Accessed November 19, 2020.

29. Haque M. Handwashing in averting infectious diseases: Relevance to COVID-19. J Popul Ther Clin Pharmacol. 2020;27(S Pt 1):e37-e52. doi:10.15586/jptcp.v27SP1.711

30. World Health Organization. WHO guidelines on hand hygiene in health care: A summary. First global patient safety challenge: Clean care is safer care. Geneva, Switzerland: WHO. 2009. https://www.who. int/gpsc/5may/tools/who_guidelines-handhygiene_summary.pdf. Accessed November 19, 2020.

31. Bert F, Giacomelli S, Ceresetti D, Zotti CM. World Health Organization framework: Multimodal hand hygiene strategy in Piedmont (Italy) health care facilities. J Patient Saf. 2019;15(4):317-321. doi:10.1097/PTS.0000000000000352

32. Kohn WG, Collins AS, Cleveland JL, Harte JA, Eklund KJ, Malvitz DM; Centers for Disease Control and Prevention (CDC). Guidelines for infection control in dental health-care settings - 2003. MMWR Recomm Rep. 2003;52(RR-17):1-61

33. Boyce JM, Pittet D; Healthcare Infection Control Practices Advisory Committee, Society for Healthcare Epidemiology of America, Association for Professionals in Infection Control, Infectious Diseases Society of America Hand Hygiene Task Force. Guideline for hand hygiene in health-care settings: Recommendations of the Healthcare Infection Control Practices Advisory Committee and the HICPAC/SHEA/APIC/IDSA Hand Hygiene Task Force. Infect Control Hosp Epidemiol. 2002;23(12 Suppl):S3-S40. doi:10.1086/503164

34. World Health Organization. Non-pharmaceutical public health measures for mitigating the risk and impact of epidemic and pandemic influenza: Annex: Report of systematic literature reviews. Geneva, Switzerland: WHO; 2019. https://apps.who.int/iris/bitstream/handle/10665/329439/WHO-WHE-IHM-GIP-2019.1-eng. pdf?sequence=1\&isAllowed=y. Accessed October 19, 2020.

35. Mathur P. Hand hygiene: Back to the basics of infection control. Indian J Med Res. 2011;134(5):611-620. doi:10.4103/0971-5916.90985.

36. Société française d'hygiène hospitalière (SFHH). Recommandations pour l'hygiène des mains. Hygiènes. 2009;XVII(3):141-240. https://sf2h.net/wp-content/uploads/2009/07/SF2H_recommandations_hygiene-des-mains-2009.pdf. Accessed October 19, 2020.

37. Australian Dental Association. ADA's Guidelines for Infection Control. $3^{\text {rd }}$ ed. St Leonards, Australia: Australian Dental Association; 2015. https://www.ada.org.au/Dental-Professionals/Publications/Infection-Control/Guidelines-for-Infection-Control/1ADA_GuidelinesforlnfectionControl_3.aspx. Accessed October 19, 2020.

38. World Health Organization. Hand hygiene: Why, how \& when? Geneva, Switzerland: WHO; 2009. https://www.who.int/gpsc/5may/Hand_ Hygiene_Why_How_and_When_Brochure.pdf. Accessed October 19, 2020.

39. Meng L, Hua F, Bian Z. Coronavirus disease 2019 (COVID-19): Emerging and future challenges for dental and oral medicine. J Dent Res. 2020;99(5):481-487. doi:10.1177/0022034520914246

40. European Centre for Disease Prevention and Control. Contact tracing: Public health management of persons, including healthcare workers, having had contact with COVID-19 cases in the European Union, 25 February 2020. Stockholm, Sweden: ECDC; 2020. https://www.ecdc.europa.eu/sites/default/files/documents/covid19-public-health-management-contact-novel-coronavirus-cases-EU.pdf. Accessed October 19, 2020.

41. McLaws ML. The relationship between hand hygiene and health care-associated infection: It's complicated. Infect Drug Resist. 2015;8:7-18. doi:10.2147/IDR.S62704

42. Sax H, Allegranzi B, Uçkay I, Larson E, Boyce J, Pittet D. 'My five moments for hand hygiene': A user-centred design approach to understand, train, monitor and report hand hygiene. J Hosp Infect. 2007;67(1):9-21. doi:10.1016/j.jhin.2007.06.004 
43. White $\mathrm{KM}$, Jimmieson $\mathrm{NL}$, Obst $\mathrm{PL}$, et al. Using a theory of planned behaviour framework to explore hand hygiene beliefs at the '5 critical moments' among Australian hospital-based nurses. BMC Health Serv Res. 2015;15:59. doi:10.1186/s12913-015-0718-2

44. Ding $\mathrm{Z}$, Qian $\mathrm{H}, \mathrm{Xu} B$, et al. Toilets dominate environmental detection of severe acute respiratory syndrome coronavirus 2 in a hospital. Sci Total Environ. 2021;753:141710. doi:10.1016/j.scitotenv.2020.141710

45. Ong SWX, Tan YK, Chia PY, et al. Air, surface environmental, and personal protective equipment contamination by severe acute respiratory syndrome coronavirus 2 (SARS-CoV-2) from a symptomatic patient. JAMA. 2020;323(16):1610-1612. doi:10.1001/jama.2020.3227

46. Kampf G, Todt D, Pfaender S, Steinmann E. Persistence of coronaviruses on inanimate surfaces and their inactivation with biocidal agents. J Hosp Infect. 2020;104(3):246-251. doi:10.1016/j. jhin.2020.01.022

47. World Health Organization. Infection prevention and control during health care when novel coronavirus ( $\mathrm{nCoV}$ ) infection is suspected: interim guidance, 19 March 2020. Geneva, Switzerland: WHO; 2020. https://www.who.int/publications/i/item/10665-331495. Accessed October 19, 2020.

48. Fathizadeh $\mathrm{H}$, Maroufi $\mathrm{P}$, Momen-Heravi $\mathrm{M}$, et al. Protection and disinfection policies against SARS-CoV-2 (COVID-19). Infez Med. 2020;28(2):185-191.

49. Al-Sayah MH. Chemical disinfectants of COVID-19: An overview. J Water Health. 2020;18(5):843-848. doi:10.2166/wh.2020.108

50. Siddharta A, Pfaender S, Vielle NJ, et al. Virucidal activity of World Health Organization-recommended formulations against enveloped viruses, including Zika, Ebola, and emerging coronaviruses. J Infect Dis. 2017;215(6):902-906. doi:10.1093/infdis/jix046

51. Rabenau HF, Cinatl J, Morgenstern B, Bauer G, Preiser W, Doerr HW. Stability and inactivation of SARS coronavirus. Med Microbiol Immunol. 2005;194(1-2):1-6. doi:10.1007/s00430-004-0219-0

52. Eggers M, Koburger-Janssen T, Eickmann M, Zorn J. In vitro bac tericidal and virucidal efficacy of povidone-iodine gargle/mouthwash against respiratory and oral tract pathogens. Infect Dis Ther 2018;7(2):249-259. doi:10.1007/s40121-018-0200-7

53. World Health Organization \& United Nations Children's Fund. Water, sanitation, hygiene and waste management for COVID-19: interim guidance, 19 March 2020. Geneva, Switzerland: WHO; 2020. https://apps.who.int/iris/handle/10665/331499. Accessed November 14, 2020

54. Goyal SM, Chander Y, Yezli S, Otter JA. Evaluating the virucidal efficacy of hydrogen peroxide vapour. J Hosp Infect. 2014;86(4):255-259. doi:10.1016/j.jhin.2014.02.003

55. Rundle $C W$, Presley $C L$, Militello $M$, et al. Hand hygiene during COVID-19: Recommendations from the American Contact Dermatitis Society. J Am Acad Dermatol. 2020;83(6):1730-1737. doi:10.1016/j. jaad.2020.07.057

56. Jing JLJ, Pei YT, Bose RJC, McCarthy JR, Tharmalingam N, Madheswaran T. Hand sanitizers: A review on formulation aspects, adverse effects, and regulations. Int J Environ Res Public Health. 2020;17(9):3326. doi:10.3390/ijerph17093326

57. Lin Q, Lim JYC, Xue K, et al. Sanitizing agents for virus inactivation and disinfection. View. 2020;e16. doi:10.1002/viw2.16

58. Kampf G, Kramer A. Epidemiologic background of hand hygiene and evaluation of the most important agents for scrubs and rubs. Clin Microbiol Rev. 2004;17(4):863-893. doi:10.1128/CMR.17.4.863-893.2004

59. Wood A, Payne D. The action of three antiseptics/disinfectants against enveloped and non-enveloped viruses. J Hosp Infect. 1998;38(4):283-295. doi:10.1016/s0195-6701(98)90077-9

60. Tysiąc-Miśta M, Dubiel A, Brzoza K, Burek M, Pałkiewicz K. Air disinfection procedures in the dental office during the COVID-19 pandemic. Med Pr. 2021;72(1):39-48. doi:10.13075/mp.5893.01005

61. Food and Drug Administration. Enforcement policy for sterilizers, disinfectant devices, and air purifiers during the coronavirus disease 2019 (COVID-19) public health emergency: Guidance for industry and Food and Drug Administration staff. Silver Spring USA: FDA; 2020. https://www.fda.gov/regulatory-information/ search-fda-guidance-documents/enforcement-policy-sterilizersdisinfectant-devices-and-air-purifiers-during-coronavirus-disease. Accessed November 15, 2020.
62. Beggs $C B$, Avital EJ. Upper-room ultraviolet air disinfection might help to reduce COVID-19 transmission in buildings: A feasibility study. PeerJ. 2020;8:e10196. doi:10.7717/peerj.10196

63. Dexter F, Parra MC, Brown JR, Loftus RW. Perioperative COVID-19 defense: An evidence-based approach for optimization of infection control and operating room management. Anesth Analg. 2020;131(1):37-42. doi:10.1213/ANE.0000000000004829

64. Humayun T, Qureshi A, AI Roweily SF, Carig J, Humayun F. Efficacy of hydrogen peroxide fumigation in improving disinfection of hospital rooms and reducing the number of microorganisms. J Ayub Med Coll Abbottabad. 2019;31(Suppl 1)(4):S646-S650.

65. Freyssenet $C$, Karlen S. Plasma-activated aerosolized hydrogen peroxide (aHP) in surface inactivation procedures. Appl Biosaf. 2019;24(1):10-19. doi:10.1177/1535676018818559

66. Binas V, Venieri D, Kotzias D, Kiriakidis G. Modified $\mathrm{TiO}_{2}$ based photocatalysts for improved air and health quality. J Materiomics. 2017;3(1):3-16. doi:10.1016/j.jmat.2016.11.002

67. Mohamed EF, Awad G. Photodegradation of gaseous toluene and disinfection of airborne microorganisms from polluted air using immobilized $\mathrm{TiO}_{2}$ nanoparticle photocatalyst-based filter. Environ Sci Pollut Res Int. 2020;27(19):24507-24517. doi:10.1007/s11356-020-08779-0

68. Sakudo A, Yagyu Y, Onodera T. Disinfection and sterilization using plasma technology: Fundamentals and future perspectives for biological applications. Int J Mol Sci. 2019;20(20):5216. doi:10.3390/ ijms20205216

69. Filipić A, Gutierrez-Aguirre I, Primc G, Mozetič M, Dobnik D. Cold plasma, a new hope in the field of virus inactivation. Trends Biotechnol. 2020;38(11):1278-1291. doi:10.1016/j.tibtech.2020.04.003

70. Otter JA, Yezli S, Barbut F, Perl TM. An overview of automated room disinfection systems: When to use them and how to choose them. In: Walker J, ed. Decontamination in Hospitals and Heathcare. $2^{\text {nd }}$ ed. Cambridge, UK: Woodhead Publishing - Elsevier; 2019:323-369. doi:10.1016/B978-0-08-102565-9.00015-7

71. Suh Y, Patel S, Kaitlyn R, et al. Clinical utility of ozone therapy in dental and oral medicine. Med Gas Res. 2019;9(3):163-167. doi:10.4103/2045-9912.266997

72. European Committee for Standardization. CEN/TC 216 - Chemical disinfectants and antiseptics. Surgical hand disinfection - test method and requirements (phase 2, step 2). Brussels, Belgium: CEN; 2018. https://standards.cen.eu/dyn/www/f?p=204:110:0::::FSP_ PROJECT,FSP_ORG_ID:65617,6197\&cs=1A4D7090064AEF2A110D16 397BC1F245B. Accessed November 19, 2020.

73. European Committee for Standardization. CEN/TC 216 - Chemical disinfectants and antiseptics. Hygienic hand disinfection - test method and requirements (phase 2, step 2). Brussels, Belgium: CEN; 2013. https://standards.cen.eu/dyn/www/f?p=204:110:0::::FSP PROJECT,FSP_ORG_ID:28420,6197\&cs=11AB47733F64AC32AC2040 1FABAA297CD. Accessed November 19, 2020.

74. Suchomel M, Eggers M, Maier S, Kramer A, Dancer SJ, Pittet D. Evaluation of World Health Organization-recommended hand hygiene formulations. Emerg Infect Dis. 2020;26(9):2064-2068. doi:10.3201/eid2609.201761

75. Sohrabi C, Alsafi Z, O'Neill N, et al. World Health Organization declares global emergency: A review of the 2019 novel coronavirus (COVID-19). Int J Surg. 2020;76:71-76. doi:10.1016/j.ijsu.2020.02.034

76. World Health Organiztion. Report of the WHO-China Joint Mission on coronavirus disease 2019 (COVID-19). Beijing, China; 2020. https://www.who.int/publications/i/item/report-of-the-whochina-joint-mission-on-coronavirus-disease-2019-(covid-19). Accessed October 19, 2020.

77. European Center for Disease Prevention and Control. Coronavirus disease 2019 (COVID-19) pandemic: Increased transmission in the EU/EEA and the UK - seventh update, 25 March 2020. Stockholm, Sweden: ECDC; 2020. https://www.ecdc.europa.eu/sites/default/ files/documents/RRA-seventh-update-Outbreak-of-coronavirusdisease-COVID-19.pdf. Accessed October 19, 2020.

78. European Center for Disease Prevention and Control. Guidance for wearing and removing personal protective equipment in healthcare settings for the care of patients with suspected or confirmed COVID-19, February 2020. Stockholm, Sweden: ECDC; 2020. https://www.ecdc. europa.eu/sites/default/files/documents/COVID-19-guidance-wearing-and-removing-personal-protective-equipment-healthcare-settings-updated.pdf. Accessed October 19, 2020 
79. Ye $G$, Lin $H$, Chen $L$, et al. Environmental contamination of the SARS-CoV-2 in healthcare premises: An urgent call for protection for healthcare workers. medRxiv preprint. 2020. doi:10.1101/2020.03.11.20034546

80. Thivichon-Prince B, Barsotti O, Girard R, Morrier J. Hand hygiene practices in a dental teaching center: Measures and improve. Eur J Dent. 2014;8(4):481-486. doi:10.4103/1305-7456.143629

81. Macias AE, de la Torre A, Moreno-Espinosa S, Leal PE, Bourlon MT, Ruiz-Palacios GM. Controlling the novel A (H1N1) influenza virus: Don't touch your face! J Hosp Infect. 2009;73(3):280-291. doi:10.1016/j.jhin.2009.06.017

82. Kwok YLA, Gralton J, McLaws ML. Face touching: A frequent habit that has implications for hand hygiene. Am J Infect Control. 2015;43(2):112-114. doi:10.1016/j.ajic.2014.10.015

83. Naeem A, Saluja SA, Krishna D, Shitanshu M, Arun S, Taseer B. Contamination of dentist's hands with and without finger rings. J Int Oral Health. 2015;7(8):114-117.

84. Pittet D, Allegranzi B, Sax H, et al.; WHO Global Patient Safety Challenge, World Alliance for Patient Safety. Evidence-based model for hand transmission during patient care and the role of improved practices. Lancet Infect Dis. 2006;6(10):641-652. doi:10.1016/S14733099(06)70600-4

85. Shinde MB, Mohite VR. A study to assess knowledge, attitude and practices of five moments of hand hygiene among nursing staff and students at a tertiary care hospital at Karad. Int J Sci Res. 2014;3(2):311-321. https://www.ijsr.net/archive/v3i2/MDIwMTM5NTc=.pdf. Accessed October 19, 2020.

86. World Health Organization. Hand hygiene in outpatient care, homebased care and long-term care facilities. A guide to the application of the WHO multimodal hand hygiene improvement strategy and the "My Five Moments for Hand Hygiene" approach. Geneva, Switzerland: WHO; 2012. https://apps.who.int/iris/bitstream/handle/10665/78060/9789241503372_eng.pdf?sequence $=1$. Accessed October 19, 2020

87. Klymenko I, Kampf G. Systemic mistakes in hand hygiene practice in Ukraine: Detection, consequences and ways of elimination. GMS Hyg Infect Control. 2015;10:Doc01. doi:10.3205/dgkh000244

88. Direction Générale de la Santé - Ministère de la Santé et des Solidarités. Guide de prévention des infections liées aux soins en chirurgie dentaire et en stomatologie. 2006. https://solidarites-sante. gouv.fr/IMG/pdf/Guide_de_prevention_des_infections_liees_ aux_soins_en_chirurgie_dentaire_et_en_stomatologie.pdf. Accessed October 19, 2020.

89. McBride ME. Microbial flora of in-use soap products. Appl Environ Microbiol. 1984;48(2):338-341. doi:10.1128/aem.48.2.338-341.1984

90. Hegde PP, Andrade AT, Bhat K. Microbial contamination of "in use" bar soap in dental clinics. Indian J Dent Res. 2006;17(2):70-73. doi:10.4103/0970-9290.29888

91. Fluent MT. Hand hygiene in the dental setting: Reducing the risk of infection. Compend Contin Educ Dent. 2013;34(8):624-627.

92. Gammon J, Hunt J. The neglected element of hand hygiene - significance of hand drying, efficiency of different methods and clinical implication: A review. J Infect Prev. 2019;20(2):66-74. doi:10.1177/1757177418815549

93. Kimmitt PT, Redway KF. Evaluation of the potential for virus dispersal during hand drying: A comparison of three methods. J Appl Microbiol. 2016;120(2):478-486. doi:10.1111/jam.13014

94. Pitten FA, Herdemann G, Kramer A. The integrity of latex gloves in clinical dental practice. Infection. 2000;28(6):388-392. doi:10.1007/s150100070011 